Agnieszka Bałdyga

Uniwersytet Warszawski

\title{
Reakcje Zachodu na wprowadzenie szariatu w Nigerii
}

DOI: http://dx.doi.org/10.12775/SIT.2014.023

Prawo szariatu ukształtowane w świecie muzułmańskim jest często przedmiotem krytyki w krajach Zachodu. Najwięcej kontrowersji budzą kary takie jak ukamienowanie, amputacja i chłosta. Obecnie są one orzekane i wykonywane w niewielu krajach muzułmańskich. W ciągu ostatnich kilkudziesięciu lat obserwuje się jednak tendencję do wprowadzania do prawa tego rodzaju kar. Na taki krok zdecydowała się m.in. północna Nigeria w 1999 r. Powrót do muzułmańskiego prawa karnego w tym kraju wzbudził zaniepokojenie na Zachodzie. Informacje o kilku procesach, które odbyły się od tego czasu w Nigerii, pojawiały się w mediach i pod ich wpływem obywatele takich państw jak Kanada oraz Wielka Brytania podejmowali akcje w obronie oskarżonych, najczęściej w formie pisania listów do władz Nigerii. Z perspektywy kilkunastu lat od wprowadzenia szariatu można podjąć próbę oceny efektów tych działań. Można również wskazać czynniki historyczne i społeczno-kulturowe, które mogą spowodować, że akcje podejmowane w obronie oskarżonych nie będą przynosiły spodziewanego efektu.

\section{Prawo szariatu w Nigerii}

W 1998 r. w Nigerii, po śmierci generała Saniego Abachy, został rozpoczęty proces powrotu do rządów cywilnych. W 1999 r. odbyły się 
pierwsze demokratyczne wybory, podczas których Nigeryjczycy głosowali m.in. na władze poszczególnych stanów. W północnej Nigerii, która jest zamieszkana głównie przez muzułmanów, jednym z najważniejszych tematów kampanii był szariat. Do tej pory prawo muzułmańskie obowiązywało tam jedynie w kwestiach dotyczących prawa cywilnego. W kampanii wyborczej, która była prowadzona od 1998 r., część polityków zaczęła domagać się wprowadzenia szariatu również w sprawach karnych. Najbardziej zagorzałym orędownikiem tego rozwiązania był Ahmad Sani Yerima, który kandydował na stanowisko gubernatora stanu Zamfara. Jego postulaty otrzymały szerokie poparcie społeczne i ostatecznie udało mu się wygrać wybory. Stan Zamfara wprowadził prawo szariatu już w styczniu 2000 r. W ślad za Zamfarą poszło pozostałe 11 stanów północnej Nigerii ${ }^{1}$.

Wprowadzenie pełnego szariatu w północnej Nigerii przez część elit politycznych było uważane za akt, który w symboliczny sposób kończył proces dekolonizacji. Szariat bowiem w sprawach karnych został zniesiony przez władze brytyjskie w okresie podboju kolonialnego. Zgodnie $z$ zasadą rządów pośrednich, którą kierowali się Brytyjczycy na podbijanych terytoriach, władza miała być sprawowana za pośrednictwem miejscowych władców i starano się jak najmniej ingerować w ich poczynania. Odstępstwem od tej reguły było podejście do wymierzania kar wynikających $z$ szariatu. Władze kolonialne uważały je za wyjątkowo okrutne i wymogły na muzułmanach $z$ podbitego kalifatu Sokoto rezygnację $z$ ich wymierzania ${ }^{2}$. Podobnie w tym zakresie wyglądała sytuacja w innych częściach Imperium Brytyjskiego ${ }^{3}$. Uzyskanie niepodległości przez Nigerię nie spowodowało powrotu do stosowania kar wynikających z szariatu. W 1960 r. w nowo powstałym państwie w północnych stanach zaczął obowiązywać Penal Code, który nie przewidywał stosowania niehumanitarnych kar, takich jak ukamienowanie i amputacja. Przyjęcie

${ }^{1}$ G.J. Weimann, Islamic Criminal Law in Northern Nigeria: Politics, Religion, Judicial Practice, Amsterdam 2010, s. 15.

2 Ibidem, s. 17 i n.

${ }^{3}$ R. Peters, Hudud, http://www.oxfordislamicstudies.com/article/opr/ t236/e0322\# (dostęp: 20 grudnia 2013 r.). 
tego aktu prawnego było rodzajem ustępstwa wobec Brytyjczyków, którzy zgodzili się na wycofanie $z$ Nigerii, a jednym $z$ warunków było wyeliminowanie nieakceptowanych praktyk ${ }^{4}$. Kompromis nie uzyskał poparcia dużej części społeczeństwa oraz elit religijnych i politycznych. Od $1960 \mathrm{r}$. wielokrotnie powracał postulat przywrócenia tych kar, nigdy jednak nie przeforsowano tego rodzaju rozwiązań ${ }^{5}$. Ta sytuacja zmieniła się dopiero w 1999 r. po zakończeniu okresu rządów wojskowych.

Postulat wprowadzenia pełnego szariatu wywołał duże zaniepokojenie wśród chrześcijan w Nigerii. Wielu z nich krytykowało w bardzo ostry sposób ten pomysł, nierzadko przy użyciu języka obraźliwego dla muzułmanów. Szariat został nawet określony jako „bestia $z$ otchłani piekielnych”. Mówiono także, że prawdziwą intencją muzułmanów jest utworzenie „islamskiej republiki Nigerii”. Działania elit politycznych północy określano jako „drugi dżihad”6. Wyrażano również obawę, że zmiana prawa wpłynie niekorzystnie na sytuację mniejszości religijnych na północy kraju, choć szariat miał być stosowany tylko w stosunku do osób wyznających islam. Te obawy były częściowo uzasadnione, szczególnie w początkowym okresie po wprowadzeniu nowego prawa. Szkody poniosły głównie osoby zajmujące się sprzedażą, produkcją i sprowadzaniem alkoholu. Było to związane $\mathrm{w}$ tym, że próbowano wówczas walczyć $\mathrm{z}$ niemoralnym zachowaniem wyznawców islamu, w tym $z$ alkoholizmem, i uznano, że pozytywny efekt nie zostanie osiągnięty, dopóki nie wyeliminuje się samego alkoholu. W związku z tym w Kano wprowadzono przepisy, które zabraniały wyrobu i sprzedaży alkoholu ${ }^{7} \mathrm{Na}$ początku ich obowiązywania dochodziło do niszczenia transportów

4 S. Piłaszewicz, Kontrowersje wokót szariatu w Nigerii, „Afryka” 2002, nr 15 , s. 32.

${ }^{5}$ E. Siwierska, Sasiedztwo nieoswojone: stosunki chrześcijańsko-muzułmańskie $w$ Nigerii, „Afryka” 2011, nr 33, s. 13.

${ }^{6}$ P. Ostien, Prefeace to Volumes I-V, w: Sharia Implementation in Northern Nigeria 1999-2006, red. P. Ostien, s. VII; http://www.sharia-in-africa.net/ pages/publications/sharia-implementation-in-northern-nigeria.php (dostęp: 28 grudnia 2013 r.).

7 P. Ostien, M.J. Umaru, Changes in the Law in the Sharia States Aimed at Suppressing Social Vices, w: Sharia Implementation, op.cit., s. 40 i n. 
wysyłanych do barów prowadzonych przez chrześcijan ${ }^{8}$. Groźniejsze w skutkach były zamieszki, które wybuchały w związku z planami wprowadzenia szariatu. W ich wyniku śmierć poniosło wiele osób. Do starć między zwolennikami oraz przeciwnikami szariatu doszło m.in. w mieście Kaduna w lutym 2000 r. W ich wyniku mogło zginąć około 2 tys. ludzi9

Politycy, którzy opowiadali się za przywróceniem szariatu, przekonywali wyborców, że dzięki temu posunięciu znacznie poprawi się jakość życia w kraju. Powrót do pełnego szariatu był przedstawiany jako najlepsze rozwiązanie problemów, z którymi boryka się Nigeria. Prawo muzułmańskie miało przede wszystkim zaradzić takim zjawiskom jak korupcja czy przestępczość. Politycy odwoływali się nawet do argumentów natury religijnej. Przekonywano, że szariat jest zgodny $z$ wolą Boga i jego wprowadzenie w związku $z$ tym zostanie przez niego wynagrodzone ${ }^{10}$. Wspomniany już polityk, Sani Yerima, przyrównywał nawet samego siebie do wielkiej postaci historycznej, Usmana dan Fodia, który zjednoczył hausańskie państwa-miasta i stworzył kalifat Sokoto. Nie wszyscy politycy wykazywali podobny entuzjazm. Większość osób wybranych na stanowiska gubernatorów wprowadziła przepisy pod wpływem presji stwarzanej przez elity religijne oraz społeczeństwo, które zostało zachęcone przykładem Zamfary. Niechęć polityków mogła wynikać z obawy o reakcję rządu federalnego, w którego gestii leży rozdzielanie funduszy dla poszczególnych regionów. Część polityków bała się również, że ich decyzja o wprowadzeniu szariatu może później przeszkodzić im w przejściu do działalności na szczeblu federalnym. Niektórzy z nich byli członkami tej samej partii co prezydent Olusegun Obasanjo, czyli People's Democratic Party (PDP), i podlegali naciskom zarówno ze strony swojej formacji politycznej, jak i rozmaitych organizacji muzułmańskich, które stały na stanowisku, że należy wprowadzić szariat $^{11}$.

8 A.W. Ibrahim, Beer Row in Northern Nigeria, BBC 13 August 2001; http:// news.bbc.co.uk/2/hi/africa/1488627.stm (dostęp: 28 grudnia 2013 r.).

9 S. Piłaszewicz, op.cit., s. 23.

${ }^{10}$ P. Ostien, op.cit., s. VII.

${ }^{11}$ G. Weimann, op.cit., s. 16 i n. 
W kodeksach karnych uchwalonych przez władze poszczególnych stanów znalazły się m.in. kary za przestępstwa należące do kategorii hudud. Samo słowo hudud oznacza w języku arabskim granicę i w kontekście prawa karnego islamu odnosi się do czynów, których człowiek nie ma prawa popełnić, ponieważ prawo boskie tego zakazuje. Przekroczenie boskiego prawa musi być w tym przypadku bardzo surowo ukarane. Katalog czynów należących do kategorii hudud jest stały i obejmuje cudzołóstwo, fałszywe oskarżenie o cudzołóstwo, kradzież, rozbój, picie wina, rebelię, odstępstwo od wiary oraz bluźnierstwo. Kary, którymi zagrożone są te przestępstwa, są ściśle określone i człowiek nie ma prawa ich zmieniać. Większość kar za przestępstwa należące do kategorii hudud jest bardzo surowa. Za popełnienie przestępstwa cudzołóstwa przewidziano ukamienowanie. Należy jednak podkreślić, że sędziowie w sądach szariackich mają dużą niezależność i najczęściej interpretują okoliczności sprawy w taki sposób, aby nie było konieczne orzekanie najsurowszych $\mathrm{kar}^{12}$. W Nigerii wprowadzono także wynikające $z$ szariatu kary za zabójstwo oraz zranienie. Prawo muzułmańskie przewiduje za te czyny możliwość zastosowania odwetu wobec sprawcy i ewentualne złagodzenie tej kary za sprawą wypłacenia diyya, czyli okupu stronie pokrzywdzonej. Przepisy oraz sama praktyka stosowania prawa w Nigerii dosyć daleko odbiegają od normy ustalonej przez twórców klasycznych szkół prawa. Przestępstwa te są ścigane obecnie $z$ oskarżenia publicznego, choć dawniej inicjatywa w tym zakresie mogła należeć tylko do pokrzywdzonego, a w przypadku zabójstwa - do jego rodziny. Prawo odwetu zakładało także stosowanie kary, która miała odzwierciedlać sam sposób popełnienia czynu. W Nigerii nie doszło do tej pory do takiego zastosowania prawa. Jedyną osobą skazaną na karę śmierci był Sani Yakubu Rodi. Mężczyzna zostały uznany za winnego potrójnego zabójstwa. Rodzina ofiar domagała się kary śmierci dla sprawcy i początkowo sąd orzekł, że powinien być dźgnięty nożem, gdyż w ten sposób zostało popełnione przez niego przestępstwo.

12 J. Bury, J. Kasprzak, Prawo karne islamu, Warszawa 2007, s. 110. 
Ostatecznie jednak metoda egzekucji została zmieniona i mężczyzna został powieszony ${ }^{13}$.

\section{Reakcje na wprowadzenie szariatu}

Wprowadzenie szariatu w zakresie spraw karnych w północnej Nigerii wywołało niepokój w świecie Zachodu. Organizacje zajmujące się obroną praw człowieka tworzyły raporty na temat regulacji prawnych oraz praktyki stosowania prawa. Najbardziej wyczerpującą publikację tego typu stworzyła Human Rights Watch ${ }^{14}$. Szariatem zajmowali się również afrykaniści, którzy analizowali zarówno stosowanie prawa, jak i społeczno-kulturowy kontekst zmian. Publikacje te wskazywały na czynniki, które spowodowały, że idea przywrócenia pełnego szariatu cieszyła się dużą popularnością w społeczeństwie północnej części kraju. Badacze zwracali uwagę m.in. na fakt, że szariat był postrzegany jako sposób na radzenie sobie $z$ przestępczością w kraju, korupcją oraz niesprawiedliwością społeczną.

Szariat zainteresował nie tylko ekspertów w świecie Zachodu. W ciągu kilku pierwszych lat obowiązywania nowych przepisów w prasie oraz na portalach internetowych ukazywały się informacje dotyczące nie tyle samych zmian w prawie, co konkretnych procesów odbywających się przed sądami szariackimi. Najwięcej emocji budziły przede wszystkim przypadki kobiet oskarżonych o cudzołóstwo, Safiyyi Husseini i Aminy Lawal. Obie oskarżone były rozwódkami, które zaszły w ciążę i na tej podstawie postawiono im zarzut popełnienia przestępstwa $z i n a^{15}$. Ze względu na fakt, że

13 G.J. Weimann, op.cit., s. 30.

14 „Political Shari'a”? Human Rights and Islamic Law in Northern Nigeria, 16, 9(A), 2004. http://www.hrw.org/reports/2004/09/21/political-shari (dostęp: 28 grudnia 2013 r.).

${ }^{15}$ Przestępstwo zina jest rozumiane jako nielegalny związek seksualny osób, które nie są ze sobą w związku małżeńskim. W przypadku osób, które zawarły kiedykolwiek w swoim życiu związek małżeński, karą za zina jest ukamienowanie. Osoby, które nie są aktualnie ani w przeszłości nie były w związku małżeńskim, przewidziana jest kara chłosty, która w przeciwieństwie do ukamienowania została zawarta w Koranie. J. Bury, J. Kasprzak, op.cit, s. 144. 
w przeszłości zawarły związek małżeński, mogły zostać skazane na karę śmierci przez ukamienowanie. Głos w obronie Husseini zabrała m.in. amerykańska Izba Reprezentantów, która wydała rezolucję $\mathrm{w}$ tej sprawie ${ }^{16}$. Publikacje $\mathrm{w}$ prasie sprawiły, że o losach kobiet dowiedzieli się również obywatele państw zachodnich. W przypadku Lawal, która została oskarżona w 2002 r., niedługo po uniewinnieniu Husseini, doszło nawet do zorganizowania akcji pisania listów $\mathrm{w}$ jej obronie. Za tą inicjatywą stali prawdopodobnie członkowie Amnesty International z południowego Londynu. Za pośrednictwem internetu zebrano wówczas 1,3 mln podpisów od obywateli ponad 100 krajów świata ${ }^{17}$. Do akcji włączyły się również uczestniczki konkursu Miss Świata, którego finał miał odbyć się w Nigerii. Część kobiet wycofała się z rywalizacji o koronę Miss Świata na znak protestu przeciwko karze ukamienowania ${ }^{18}$. Głos w sprawie Lawal zabrał również Bill Clinton, prosząc o jej ułaskawienie ${ }^{19}$.

\section{Czynniki wpływające na skuteczność interwencji}

Powstaje pytanie o skuteczność tych interwencji. Bardzo często dochodzi do kwestionowania dobrych intencji obywateli państw zachodnich włączających się w takie akcje. W rezultacie mogą one nawet zaszkodzić osobom, których dotyczą. O takim niebezpieczeństwie alarmowały np. członkinie organizacji BAOBAB for Women's Human Rights, które wystosowały list $z$ apelem o zaprzestanie prowadzenia kampanii $\mathrm{w}$ obronie Lawal ${ }^{20}$. Członkinie tej organi-

${ }^{16}$ http://www.gpo.gov/fdsys/search/pagedetails.action?packageId=BILLS107hconres351ih (dostęp: 22 grudnia 2013 r.).

17 L. Brooks, Saving Amina, „The Guardian” 8 May 2003, http://www.theguardian.com/world/2003/may/08/gender.uk (dostęp: 22 grudnia 2013 r.).

${ }_{18}$ Miss World Nigeria Boycott Spreads, BBC 6 August 2002, http://news. bbc.co.uk/2/hi/world/africa/2240790.stm. (dostęp: 28 grudnia 2013 r.).

19 http://www.breakingnews.ie/world/clinton-pleads-for-life-of-womancondemned-to-stoning-69710.html (dostęp: 28 grudnia 2013 r.).

20 Sharia Implementation in Nigeria: The Journey so far, http://baobabwomen.org/publications_womenshr.htm\#Sharia_Implementation_in_Nigeria:_The_Journey_so_far (dostęp: 20 grudnia 2013 r.). 
zacji działającej na terenie Nigerii zwracają uwagę, że interwencje w tej sprawie są źle odbierane przez elity polityczne oraz część społeczeństwa. Organizacja BAOBAB od momentu wprowadzenia szariatu działa na rzecz osób oskarżonych i z dużymi sukcesami reprezentuje je przed sądami szariackimi. Zdaniem autorek listu, Ayeshy Imam oraz Sindi Medar-Gould, kampania polegająca na wysyłaniu listów, może spowodować efekt przeciwny do zamierzonego. Zwracają uwagę na konieczność opierania się na potwierdzonych informacjach podczas przygotowywania treści listu. Błąd tego rodzaju popełnili autorzy wspomnianego apelu, z którego wynikało, że Lawal została skazana i wyznaczono już datę egzekucji. W rzeczywistości sąd pierwszej instancji wydał wyrok skazujący, natomiast w momencie, gdy zaczęła się akcja wysyłania e-maili, kobieta czekała na rozprawę przed sądem apelacyjnym, który ostatecznie doprowadził do jej uniewinnienia ${ }^{21}$. Tego rodzaju błędy bądź przekłamania stawiają $\mathrm{w}$ trudnej sytuacji NGO-sy zajmujące się reprezentowaniem oskarżonych przed sądem, ponieważ podważają ich wiarygodność. W przekonaniu zwolenników szariatu to właśnie te organizacje są odpowiedzialne za przekazywanie niepełnych lub wręcz kłamliwych informacji ${ }^{22}$.

Inną ważną kwestią dotyczącą treści apeli wysyłanych w obronie osób oskarżonych jest kierowanie się stereotypami na temat muzułmanów oraz islamu przez ich autorów. Niezręczne sformułowania mogą zostać odebrane jako atak i nie będą sprzyjać stwarzaniu atmosfery do dialogu. Imam oraz Medar-Gould zwracają uwagę na zagrożenie związane $z$ grupami młodych ludzi, którzy należą do straży obywatelskich. Tego rodzaju grupy, zwane hisbami, powstały natychmiast po wprowadzeniu szariatu. Celem hisb jest propagowanie wartości wynikających $z$ islamu, a także dbanie o porządek i bezpieczeństwo. Ich członkowie charakteryzują się zazwyczaj dużym poziomem zaangażowania religijnego. Działalność hisb wzbudza wiele kontrowersji, ponieważ nie zawsze stosują pokojowe metody. W ciągu kilku pierwszych lat ich funkcjonowania dochodziło do przypadków pobić podejrzanych oraz niszczenia ich

\footnotetext{
${ }^{21}$ L. Brooks, op.cit.

22 Sharia Implementation, s. 31.
} 
mienia $^{23}$. Członkowie hisb mają niechętny stosunek do organizacji zapewniających pomoc prawną osobom oskarżonym. Według nich już samo odwoływanie się od wyroku jest niezgodne $z$ zasadami islamu i takie działanie można nawet przyrównać do apostazji. Imam oraz Medar-Gould podkreślają, że ze względu na radykalizm tych młodych ludzi, należy szczególnie zwracać uwagę na pojawiające się w apelach sformułowania, które mogłyby w jakikolwiek sposób sprawiać wrażenie, że atakują islam. Autorki apelu podkreślają, że $\mathrm{z}$ wielkim szacunkiem podchodzą do religii muzułmańskiej. Zwracają również uwagę na nierzetelny sposób przedstawienia islamu oraz spraw dotyczących wydarzeń w Afryce w zachodnich mediach $^{24}$.

Ważnym aspektem krytyki zachodnich interwencji jest sam wybór spraw, w których wystosowywane są apele i rezolucje wydawane przez poszczególne państwa oraz organizacje międzynarodowe. Do tej pory wielkie akcje podejmowano wyłącznie w sprawach kobiet, które miały dopuścić się cudzołóstwa. Podobne interwencje nie były natomiast przeprowadzane w przypadku osób oskarżonych o kradzież i narażonych na obcięcie dłoni. W odróżnieniu od poprzednio omawianego rodzaju kary, procesy w takich sytuacjach nie zawsze kończyły się pomyślnie i w kilku przypadkach przeprowadzono amputacje. Informacje o osobach, które zostały pozbawione dłoni, nie wzbudzały jednak podobnych emocji jak historie Lawal oraz Husseini. Innym interesującym aspektem jest to, że opinia publiczna na Zachodzie nie była $z$ podobnym natężeniem informowana o tym, że kara ukamienowania groziła nie tylko kobietom. W większości przypadków rzeczywiście nie pociągano mężczyzn do odpowiedzialności za popełnienie zina, a jedynie ich partnerki. Jednakże doszło do kilku procesów, w których na ławie oskarżonych zasiedli zarówno kobieta, jak i mężczyzna. Kara ukamienowania groziła na przykład Ahmadu Ibrahimowi ze stanu Niger. Został on oskarżony wraz ze swoją partnerką Fatimą Usman ${ }^{25}$. Groźba skazania mężczyzny na karę śmierci przez ukamienowanie była równie realna jak w przy-

\footnotetext{
${ }^{23}$ E. Siwierska, op.cit., s. 80 i n.

${ }^{24}$ Sharia Implementation, s. 31.

25 „Political Shari'a”?, s. 25.
} 
padku Lawal oraz Husseini, ale sprawa nie wywołała wielkiego poruszenia w świecie Zachodu. Ponadto na karę ukamienowania mogły zostać skazane osoby, które dopuściły się gwałtu na dzieciach. W 2002 r. w miejscowości Dutse w stanie Jigawa Sarimu Mohammed Baranda został skazany przez sąd pierwszej instancji na karę ukamienowania za zgwałcenie dziewięcioletniej dziewczynki. Namówiony przez swoją rodzinę mężczyzna odwołał się od wyroku. Jego adwokat przekonywał sąd, że Sarimu Mohammed Baranda nie może zostać skazany na karę ukamienowania, ponieważ jest chory psychicznie. Ostatecznie sąd uznał argumenty apelacji i mężczyzna uniknął egzekucji ${ }^{26}$. Zachodnie media poświęciły niewiele uwagi tej sprawie. Nie prowadzono również akcji w obronie Barandy.

Skupienie na obronie praw kobiet może być odbierane jako przejaw neokolonialnych dążeń Zachodu. Kwestia traktowania kobiet, podobnie jak stosowanie kar obcych kulturze europejskiej w świecie muzułmańskim, była przedmiotem krytyki już w czasach kolonialnych. Wówczas te argumenty były używane w dużej mierze w celu usprawiedliwienia podboju ludów uznawanych za mniej cywilizowane. O trudnej sytuacji kobiet w kulturze islamu przekonywały nawet osoby, które jednocześnie nie wykazywały żadnego zrozumienia dla postulatów sufrażystek w swojej ojczyźnie. Osobą stosującą podwójne standardy w tym zakresie był na przykład Lord Cromer, który ubolewał nad losem Egipcjanek i jednocześnie należał do organizacji Men's League for Opposing Women's Suffrage sprzeciwiającej się przyznaniu prawa głosu kobietom ${ }^{27}$. Wykorzystywanie feministycznych haseł i postulatów w epoce kolonialnej w celu uzasadnienia podbojów doprowadziło do utożsamienia idei praw kobiet i równości płci $z$ kolonializmem na niektórych obszarach dawnego Imperium Brytyjskiego. Ruchy dążące do uzyskania niepodległości, odrzucając ingerencję w swoją kulturę, sprzeciwiały się więc także postulatom feministycznym. Gdy krytyce podlegały obyczaje związane $z$ sytuacją kobiet, bronienie lub nawet afirmowanie pewnych praktyk stało się aktem oporu. Utożsamienie idei praw kobiet

${ }^{26}$ Ibidem, s. 33.

${ }^{27}$ L. Ahmed, Women and Gender in Islam: Historical Roots of a Modern Debate, New Haven-London, 1992, s. 153. 
z kolonializmem stanowi obecnie ogromne utrudnienie dla działalności organizacji feministycznych w krajach powstałych po zakończeniu okresu kolonialnego. Feminizm nadal jest postrzegany przez wpływowe środowiska jako zagrożenie dla rodzimej kultury.

Wiele organizacji, które zajmują się obroną praw człowieka, ma świadomość, że muszą brać pod uwagę miejscowe uwarunkowania, planując metodę interwencji. Raport Human Rights Watch podkreśla, że nie zajmuje się oceną szariatu, a jego celem jest przedstawienie praktyki stosowania prawa i sytuacji, w których naruszane są prawa człowieka ${ }^{28}$. Organizacja Amnesty International zdecydowanie odcięła się od autorów apelu o uniewinnienie Lawal, a Lesley Warner, rzecznik prasowy, podkreślił, że ich strategia działania polega na współpracy z NGO-sami w Nigerii. W wypowiedzi dla „The Guardian” stwierdził także, że powodzenie w tego rodzaju sprawach jest bardziej prawdopodobne, gdy nie są one relacjonowane $\mathrm{w}$ mediach ${ }^{29}$. Tego rodzaju wyczucia oraz delikatności zabrakło natomiast organizatorom konferencji w Rzymie, na którą zaproszono Husseini niedługo po jej uniewinnieniu. Husseini pojechała tam na zaproszenie włoskich polityków i otrzymała honorowe obywatelstwo od burmistrza Rzymu, Waltera Veltroni. Jej wyjazd wywołał duże kontrowersje w Nigerii. Gubernator stanu Sokoto, z którego pochodzi Husseini, próbował nawet uniemożliwić jej podróż do Włoch i zwrócił się do odpowiedniej instytucji, aby nie wydawała kobiecie paszportu. Polityk stwierdził później, że jego wysiłki zniweczyła Minister Spraw Kobiet, która osobiście dostarczyła Husseini dokument potrzebny do wyjazdu ${ }^{30}$. Decyzja kobiety o odbyciu tej podróży została skrytykowana nie tylko przez zwolenników szariatu, ale nawet przez organizację WRAPA (Women's Rights Advancement and Protection Alternative), która wcześniej zapewniła jej pomoc prawną. WRAPA zdecydowanie zdystansowała się od tej sprawy z obawy przed możliwymi negatywnymi następstwami dla osób, które będą stawać w przyszłości przed sądami szariacki-

28 „Political Shari'a”?, op. cit., s. 1.

${ }^{29}$ L. Brooks, op. cit.

${ }^{30}$ Nigerian woman made Rome citizen, BBC 9 August 2002, http://news. bbc.co.uk/2/hi/africa/2246838.stm (dostęp: 28 grudnia 2013 r.). 
$\mathrm{mi}^{31}$. Najostrzej na decyzję o wyjeździe zareagowali politycy z północnej Nigerii. Sani, gubernator stanu Zamfara, powiedział, że zaproszenie nie jest dla niego zaskakujące, ponieważ przeczytał gdzieś, że we Włoszech jest dużo prostytutek i $z$ chęcią wysłałby tam wszystkie kobiety lekkich obyczajów ${ }^{32}$. Poczucie, że zaproszenie Husseini miało być prowokacją wobec muzułmanów, było powszechne. Abdulkadir Orire, sekretarz generalny Jama'atu Nasril Islam, organizacji zrzeszającej wiele stowarzyszeń muzułmańskich w kraju, określił pomysłodawców wyjazdu Safiyyi jako wrogów Allaha i powiedział, nie bez racji, że: „Jeśli ktokolwiek powinien być uhonorowany, to powinien to być sędzia, który ją uwolnił”. Ta wypowiedź bardzo dobrze oddaje nastroje dużej części muzułmanów zainteresowanych tą sprawą. Wielu z nich sprzeciwiało się ukaraniu kobiety i ucieszyło się z wyroku uniewinniającego, ale nagrodzenie jej potraktowało jako prowokację wobec wyznawców islamu. Władze Rzymu tymczasem wydawały się zupełnie nieświadome reakcji, które mogą pojawić się w Nigerii. Burmistrz Walter Veltroni powiedział o tym wyróżnieniu w następujący sposób: „Chcemy, aby obywatelstwo, które dajemy symbolicznie Safiyyi, było impulsem do zniesienia kary śmierci na całym świecie i uznania praw kobiet, przy poszanowaniu religijnej oraz kulturowej różnorodności”"33. Reakcje na to wydarzenie w Nigerii świadczą z całą pewnością o tym, że ten cel nie został osiągnięty.

Organizatorzy akcji w sprawie dwóch oskarżonych kobiet twierdzą, że przyczynili się do ich uniewinnienia. Rozstrzygnięcie, czy to ich działania doprowadziły do pomyślnego zakończenia sprawy, jest niemożliwe, ponieważ na decyzję sędziego ostatecznie mogły wpłynąć różne inne czynniki. O tym, że przy interwencjach należy zachować daleko idącą ostrożność, świadczy historia Bariyi Ibrahim Magazu, która została oskarżona o cudzołóstwo. Podstawą do postawienia zarzutów, podobnie jak w dwóch poprzednio omówionych przypadkach, była ciąża. Ibrahim Magazu mogła mieć wówczas od

31 A. Musa-Yawuri, On defending Safiyatu Hussaini and Amina Lawal, w: Sharia Implementation, s. 135.

${ }^{32}$ G.J. Weimann, op.cit., s. 149.

33 Nigerian woman, op.cit. 
14 do 17 lat. Gdy dowiedziano się o ciąży, nastolatka powiedziała, że została zgwałcona przez trzech mężczyzn. Przed sądem jej wersję wydarzeń potwierdziło siedmiu świadków, ale uznano, że ich zeznania nie są wiarygodne. Sąd skazał ją na karę chłosty za seks przedmałżeński. Dodatkowo orzekł wobec niej karę 80 batów za fałszywe oskarżenie o cudzołóstwo ${ }^{34}$. Sprawa Magazu spotkała się z bardzo dużym zainteresowaniem wśród czytelników kanadyjskiej gazety, ukazującej się w Toronto, „The Globe and Mail”. Po opublikowaniu pierwszej informacji na ten temat zaczęły napływać listy do redakcji od osób, które chciały w jakiś sposób pomóc oskarżonej w uniknięciu kary. Sprawa była przedstawiana w gazecie przez wiele tygodni, a reporterka Stephanie Nolen pojechała nawet do Nigerii, aby spotkać się z Magazu. W sprawie oskarżonej wysyłane były listy $z$ apelem o jej uniewinnienie. Tym razem jednak obrona nie przyniosła pozytywnego efektu. Mimo że Ibrahim Magazu miała zamiar odwołać się od wyroku pierwszej instancji, o czym sąd był poinformowany, sędzia nieoczekiwanie oznajmił, że nie ma ona do tego prawa, a kara zostanie wykonana następnego dnia. Tak też się stało. Ibrahim Magazu wymierzono 100 batów. Uniknęła natomiast kary za fałszywe oskarżenie o cudzołóstwo, ponieważ wcześniej pod wpływem presji społecznej wycofała swoje zeznania. Wiele wskazuje na to, że na taką decyzję sędziego wpływ mogły mieć naciski zachodniej opinii publicznej. Wcześniej zapewniano, że kara zostanie wykonana dopiero, gdy Ibrahim Magazu przestanie karmić piersią swoje dziecko. Ponadto poinformowanie o tym, że kara zostanie wykonana następnego dnia, było najprawdopodobniej celowe i chodziło w tej sytuacji o uniemożliwienie wniesienia apelacji przez obronę. W przypadku Ibrahim Magazu najprawdopodobniej próby jej obrony doprowadziły do przyspieszenia egzekucji. Po wykonaniu kary media kanadyjskie, które wcześniej szeroko informowały o tej sprawie, przestały się nią interesować. W „The Globe and Mail” ukazała się jedynie krótka informacja o tym, że dziewczyna zostanie wydana za mąż za ponad trzydziestoletniego mężczyznę ${ }^{35}$.

34 „Political Shari'a”?, s. 61.

${ }^{35}$ R. E. Howard-Hassmann, The Flogging of Bariya Magazu: Nigerian Politics, Canadian Pressures and Women's ann Children's Rights, s. 1-3, http://global- 
Organizacja zrzeszająca kobiety żyjące w krajach muzułmańskich, Women Living Under Muslim Laws, opracowała wytyczne, którymi powinny kierować się osoby, które planują podjęcie protestu w formie wysyłania listów. Oprócz kwestii poruszonych przez członkinie BAOBAB for Women's Human Rights, zwracają uwagę na wybór adresata apelu ${ }^{36}$. Na przykładzie Nigerii, można stwierdzić, że nawet na tak podstawowym poziomie popełniane są błędy, które mogą być tragiczne w skutkach. Listy pisane w sprawie Lawal były kierowane do prezydenta Nigerii Oluseguna Obasanjo, który nie mógł nic zrobić w sprawie kobiety. Decyzję o odstąpieniu od wymierzenia kary mógł podjąć jedynie gubernator stanu. Niebezpieczeństwo zwracania się do prezydenta Nigerii wiązało się również $\mathrm{z}$ faktem, że jest on chrześcijaninem i w razie gdyby podjął próbę interwencji, prawdopodobnie zostałaby potraktowana jako nieuprawnione kwestionowanie prawa muzułmańskiego ${ }^{37}$.

\section{Podsumowanie}

Podejmowanie interwencji w krajach o odmiennej kulturze jest bardzo delikatną kwestią. W takim przypadku kluczowa jest znajomość uwarunkowań kulturowych, społecznych oraz historycznych, które mogą mieć wpływ na wynik tego rodzaju działań. Przykłady niektórych organizacji pokazują, że są one świadome ograniczonych możliwości interwencji. Niestety tego wyczucia brakuje wtedy, gdy akcje podejmowane są spontanicznie. Osoby poruszone historiami kobiet zagrożonych karą ukamienowania zazwyczaj nie mają rozbudowanej wiedzy na temat sytuacji panującej w kraju, z którego pochodzą te kobiety, ale czują moralny przymus do działania. Inter-

autonomy.ca/global1/servlet/Xml2pdf?fn=RA_Hassmann_Magazu (dostęp: 28 grudnia 2013 r.).

36 Solidarity Actions: the Letter Writing Campaign, http://www.wluml.org/ node/5603 (dostęp: 28 grudnia 2013 r.).

37 A. M. Imam, Women's Reproductive and Sexual Rights and the Offense of Zina in Muslim Laws in Nigeria, w: Where Human Rights Begin: Health, Sexuality, and Women in the New Millennium, red. W. Chavkin, E. Chesler, Piscataway 2005, s. 85 i n. 
wencje w takim przypadku, jak pokazała sprawa Ibrahim Magazu, mogą nie przynieść zamierzonych efektów. Planowanie działań na rzecz osób zagrożonych drastycznymi karami powinno być zawsze oparte na wiedzy pochodzącej od ekspertów znających kulturę, religię, politykę oraz sytuację społeczną na danym obszarze. Pomoc doświadczonych osób w sformułowaniu apeli może polegać na doborze odpowiedniego języka, który nie urazi adresatów, na wyeliminowaniu nieprawdziwych informacji, np. generalnych stwierdzeń na temat religii i kultury, na wyborze odpowiedniego momentu na wystosowanie listu lub nawet na nakłonieniu do rezygnacji $z$ tej formy protestu.

\section{STRESZCZENIE}

Reakcje Zachodu na wprowadzenie szariatu w Nigerii

W 2000 i 2001 r. 12 stanów północnej Nigerii ponownie wprowadziło muzułmańskie prawo karne. Nowe szariackie kodeksy karne zawierały kary za przestępstwa należące do kategorii hudud: karę śmierci przez ukamienowanie, amputację oraz chłostę. Procesy kobiet oskarżonych o cudzołóstwo wywołały zainteresowanie mediów w niektórych krajach zachodnich. Obywatele tych państw organizowali akcje pisania listów, aby wywrzeć presję na nigeryjskich polityków oraz sądy szariackie. Eksperci oraz nigeryjskie organizacje pozarządowe dowodzą, że ten rodzaj interwencji może być nieskuteczny, a nawet narazić na niebezpieczeństwo zarówno podsądnych, jak i lokalnych działaczy.

Słowa kluczowe: Szariat, północna Nigeria, kara.

\section{SUMMARY}

The responses of the West to the introduction of shari'a in Nigeria

In 2000 and in 2001 twelve states of Northern Nigeria reintroduced shari'a criminal law. New Shari'a Penal Codes included punishments for hudud offences: capital punishment by stoning, amputation and flogging. 
Trials of women accused of adultery gained media attention in some western countries. Citizens of these countries organized letter writing campaigns to assert pressure on Nigerian politicians and shari'a courts. Experts and Nigerian NGOs argue that this type of intervention can be inefficient and may even put in danger both defendants and local activists.

Keywords: Shari'a, northern Nigeria, punishment.

\section{BIBLIOGRAFIA}

Imam A. M., Women's Reproductive and Sexual Rights and the Offense of Zina in Muslim Laws in Nigeria, w: Where Human Rights Begin: Health, Sexuality, and Women in the New Millennium, red. W. Chavkin, E. Chesler, Piscataway 2005.

Bury J., Kasprzak J., Prawo karne islamu, Warszawa 2007.

Danecki J., Specyfika prawa muzułmańskiego, w: Prawo i ład społeczny: integralnokulturowa analiza zagadnienia racjonalności. Artykuły i szkice, red. J. Utrat-Milecki, Warszawa 2011.

Ahmad L., Women and Gender in Islam: Historical Roots of a Modern Debate, New Haven-London 1992.

Piłaszewicz S., Kontrowersje wokót szariatu w Nigerii, „Afryka” 2002, nr 15.

Saving Amina Lawal: Human Rights Symbolism and the Dangers of Colonialism, „Harvard Law Review” May 2004, Nr 117/7.

Siwierska E., Na straży szariatu: hisba w pótnocnej Nigerii, „Afryka” 2009, nr 29/30.

Siwierska E., Sasiedztwo nieoswojone: stosunki chrześcijańsko-muzułmańskie $w$ Nigerii, „Afryka” 2011, nr 33.

Weimann G. J., Islamic Criminal Law in Northern Nigeria: Politics, Religion, Judicial Practice, Amsterdam 2010. 